\title{
Conservation of the Natura 2000 Areas in the Context of Environmental Changes in Past and Present: a Case from the Polish Carpathians Geoheritage
}

\author{
Zofia Alexandrowicz $^{1} \cdot$ Witold Paweł Alexandrowicz ${ }^{2}$ (D) Krzysztof Buczek $^{1}$
}

Received: 21 March 2017 / Accepted: 26 April 2018 / Published online: 28 May 2018

(C) The Author(s) 2018

\begin{abstract}
The Ecological Network Natura 2000 project has been implemented in Poland since 2004, based on the Act on Nature Conservation. The Natura 2000 areas are often distinguished by particular values of the geological heritage, and sometimes also of cultural heritage. According to the premises of the programme, natural habitat should be identified by the conditions of occurrence and mutual relationships between the abiotic and biotic elements. Despite this assumption, in many cases, their valuation and description of the abiotic features is too cursory, and sometimes, it is even lacking. The valley of the Tarnawka River in the Polish Carpathians is the selected example of a Natura 2000 area. The presented characteristic of this area constitutes a supplement to its importance in the field of geological and cultural heritage. Also documented was the history of causes and changes of the natural environment dating back to the early Middle Ages. The physiographic characteristic of the area and the results of analysing the past transformations of its environment provide very rich material. It should be useful and used not only to supplement the importance of the area but also to conduct the comparative evaluation of the current and potential changes and threats caused by natural processes but, above all, by human activities.
\end{abstract}

Keywords Natura 2000 - Geological sites · Natural diversity · Environmental changes · Carpathian Mts · Poland

\section{Introduction}

The Ecological Network Natura 2000 is a system for the protection of the natural heritage of Europe, created within the framework of European Union directives in force within its member states and the accession of new states. These directives enable the delineation of special protection areas for bird

Witold Paweł Alexandrowicz

wpalex@geol.agh.edu.pl

Zofia Alexandrowicz

alexandrowicz@iop.krakow.pl

Krzysztof Buczek

buczek@iop.krakow.pl

1 Institute of Nature Conservation, Polish Academy of Sciences, Al. Mickiewicza 33, 31-120 Kraków, Poland

2 Faculty of Geology, Geophysics and Environmental Protection, AGH University of Science and Technology, Al. Mickiewicza 30, 30-059 Cracow, Poland conservation (Birds Directive - 79/409/EEC) and the conservation of the wild species of fauna and flora (Habitats Directive - 92/43/EEC), characteristic of the particular biogeographical regions of Europe. As applied to the Natura 2000 network, natural habitat as a concept used in the legal terminology of the European Union is defined by the geographical and ecological conditions of the environment. The ecological indicators of the environment pertain to both biotic and abiotic elements, since they jointly provide the natural diversity of a given type of habitat. Compared with biotic conditions, the abiotic conditions of the types of Natura 2000 habitats are usually much less recognised. They undergo constant changes, slow or rapid, depending on the course of natural geomorphological processes and anthropogenic influence. The latter increasingly contributes to the contemporary transformations of the natural environment in all climatic zones. Dynamically operating physical processes that are caused by the factors of the natural evolution of relief or by human economic activities usually appear as long-term consequences in the state of geodiversity, morphodiversity, and biodiversity in particular areas (Naylor et al. 2002; Gill et al. 2015; Lawler et al. 2015). 
These kinds of potential threats should be taken into account in the strategies of all nature conservation programmes.

The advancement of proceeding with the creation of the Natura 2000 network differs in particular countries. One of the principal problems with its implementation is the lack of sufficient awareness of the societies of the objectives and requirements of the programme. The conflicts between local communities and administrative authorities hamper the implementation of tasks, particularly of environmental monitoring (Iojă et al. 2016). In Poland, Natura 2000 activity is one of the categories of protection introduced in 2004 into the amended Nature Conservation Act. This relatively and positively affects the development of the network. Until the present, the network of Natura 2000 areas includes some $20 \%$ of the Polish territory. These areas, particularly those of great size, and distinct for high geo- and biodiversity, predominantly coincide with the national network of sites covered by various legal forms of nature protection (Alexandrowicz 2004a; Alexandrowicz et al. 2004a).

The objective of this paper is to draw attention to the exceedingly one-sided valuation of the Natura 2000 sites that frequently omits evaluation of their abiotic elements. Including them can complement the present valuation of the stage of nature areas selected for the implementation of tasks in the programme of nature conservation under discussion. The geological and geomorphological locations, usually involving small surfaces, are important to biodiversity, because many of them often form diverse microenvironments that are beneficial to the development of selected priority species of fauna and flora (Alexandrowicz et al. 2004b; Brancucci et al. 2004; Alexandrowicz and Alexandrowicz 2006; Alexandrowicz and Margielewski 2010; Gray 2013; Matthews 2014; Hjort et al. 2015). In Poland, these sites principally include the protected monuments of nature and documented sites. They occur individually or in groups and often represent interesting fragments of nature, which demonstrate the coherence of its diverse elements. The selected example of such an area in the Outer (Flysch) Carpathians is the basin of the Tarnawka River (Fig. 1). The area is extremely interesting because of its situation within the differing geological structures, which are well reflected in the landscape of the borderlands between the Beskid Wyspowy Mts and the Wiśnicz Foothills. Apart from the biological and cultural values of the Tarnawka River drainage area, the paper presents, its geological setting, the characteristics of the river gorge and of the rocky landforms in the scenic sandstone landscape. An innovative proposal, supplementing the characteristics of the studied area of Natura 2000 site, includes the results of the analysis in the natural environment occurring in historical time, determined on the basis of the assemblages of subfossil molluscs occurring in sediments. This analysis permits the determination of the environmental phases essentially affecting the course of natural processes within the protected area.

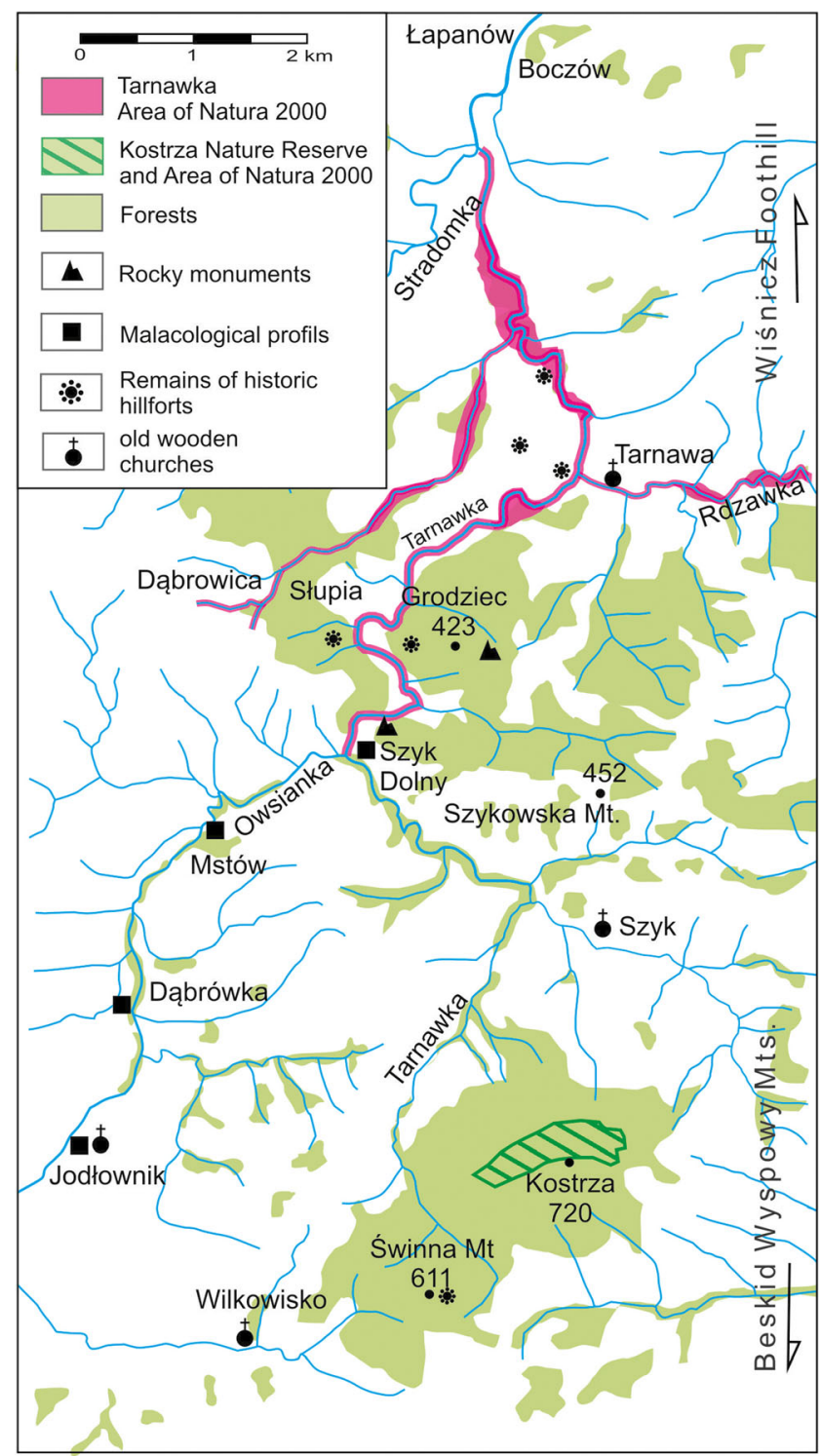

Fig. 1 The distribution of important geological, morphological, and cultural sites in the vicinity of the Tarnawka River area of Natura 2000

\section{Study Area}

The water head of the Tarnawka River includes many streams flowing from the slopes of the Beskid Wyspowy Mountains, chiefly the hills of Kostrza (720 m a.s.1.) and Świnna Góra (611 m a.s.l.) (Fig. 1). In 2001, steep, highly elevated, northern, and northwestern slopes of the former hill were placed under protection, as a nature reserve under the name "Kostrza." Its limits overlap almost perfectly with the limits of the special area for the protection of forest habitats Natura 2000 (Fig. 1). The Tarnawka River with right-bank and leftbank tributaries is, however, included in the Natura 2000 programme as a special area of protection for natural habitats typical of a natural, foothill valley of the size of approx. 140 ha (Mróz and Perzanowska 2001; Perzanowska and 
Grzegorczyk 2009) (Fig. 1). The fragment of the main valley is $7.8 \mathrm{~km}$ long and spans from the Szyk Dolny locality to the mouth of the Stradomka River.

In the basin of the Tarnawka River, there are different types of habitats. The windings of the river's meanders are covered by gravelbanks, and among them, oxbow lakes and small ponds are periodically formed, and pioneering vegetation also invades the site. The river banks and mouths of streams are overgrown by hydrophilous tall herb fringe communities of the montane to alpine levels, including willow bush, and alluvial willow, poplar, alder, and ash woods. In the surroundings of the gorge section of the valley, mixed forests with certain proportions of old beeches and firs occur. At some places, there are the outcrops of sandstones and rock screes, and among them are rock shelters and small caves. Within the lower course of the river with a meandering bed and low terrace, there are chiefly well-managed hay meadows. The diversity of habitats occurring in the Tarnawka River valley and in its immediate surroundings contributes to its being an important refuge and place of the breeding for many animal species, particularly for birds, ichtiofauna (e.g. Barbus carpathicus and Cottus gobio), and amphibians. The sites with such amphibians like the yellow-bellied toad Bombina variegata and crested newt Triturus cristatus occur at the limits of their biogeographical regions, where alpine and continental regions are particularly worth attention in the Carpathian Foothills.

The spreading of the identified types of natural habitats in the Tarnawka River valley and around it clearly corresponds to the principal features of the geological structure in the study area. The Tarnawka River valley is situated in the Outer (Flysch) Carpathians, in the zone of the overthrust of the Magura Nappe on to the Silesian Nappe (Fig. 2) (Burtan and Skoczylas-Ciszewska 1964; Radwanek-Bak 2009). The tectonics of the substrate determines closely the characteristics of relief and the geodiversity of the given area.

The Polish Carpathians are famous for their numerous sacred historic buildings, such as churches and chapels of various ages. Particularly exceptional are late-Medieval Roman Catholic wooden churches. In 2003, some from those located in the Southern Lesser Poland Voivodeship were placed on the UNESCO of World Heritage Sites. In Europe, it is the oldest grouping of wooden Medieval Churches with well-preserved elements of early-Gothic architecture. In the neighbourhood of the Tarnawka River valley, there are four historic churches (Fig. 1).

In the hills around the Tarnawka River, there are traces of prehistoric and medieval fortified settlements in the form of remnants of protective ramparts once strengthened with soil, wooden structures, and blocks of sandstones. At present, the places are marked within forest by chaotic accumulations of rocky blocks. Some names of hills or localities correspond to these cultural objects. Until the present, in the neighbourhood of the Tarnawka River valley, six old fortified settlements were identified that were inhabited at the times of different cultures (Leńczyk 1983; Marszałek 1993; Wacławik and Bajer 2014) (Fig. 1). The relics of the oldest settlements date back to the Lusatian Bronze epoch, approx. 1300-1100 BP.

\section{Geological and Geomorphological Features}

\section{Geological Setting}

Some zones of overthrusts of primary tectonic units in the Flysch Carpathians are characterised by chaotic complexes of deposits (Jankowski and Margielewski 2014). The studied area of Natura 2000 and its surroundings are situated within the border area between the Beskid Wyspowy Mts and Wiśnicz Foothill. At the same time, it is the zone of the front of Magura Nappe overthrust over the Silesian Nappe (Burtan and Skoczylas-Ciszewska 1964; Radwanek-Bąk 2009) (Fig. 2). It has an enormously complex geological structure corresponding to chaotic complexes. These are characterised by the melange of deposits, strong tectonic deformations, numerous inversions of structures, and out-of-sequence thrusts. Along the front of overthrust, there is also a separated fragment of the Magura Nappe, representing the type of block matrix within chaotic complexes (Burtan and SkoczylasCiszewska 1964; Jankowski and Margielewski 2014). In its surroundings, there are the melange deposits of the Silesian Nappe, where the formations of the sub-Silesian series are exposed in several places, and they are now referred to as "tectonic windows."

The source area of the Tarnawka River as well as its upper course occur within the abovementioned separate part of the Magura Nappe, represented by the formation of Eocene Magura sandstones. Here, the northernmost heights of the Beskid Wyspowy Mts are situated (e.g. Kostrza and Świnna Mt.) (Fig. 1). The hills surrounding the gorge section of the valley are built by layers of the Istebna Sandstone Formation (Upper CretaceousPalaeocene) of the Silesian Nappe. In the lower course of the Tarnawka River, the Quaternary sediments of loess and river mud types cover the older substrate.

The chaotic complexes influence the forms of relief (Jankowski and Margielewski 2014). In the study area, the extraordinarily abundant development of stream valleys and gorges can be associated with this influence. The internal occurrence of numerous gravitational translocations of weathered covers and rock fragments formed during the disintegration of slipped sandstone beds resulting from disintegration of slipped beds of sandstones are also linked to this influence (Fig. 3). 


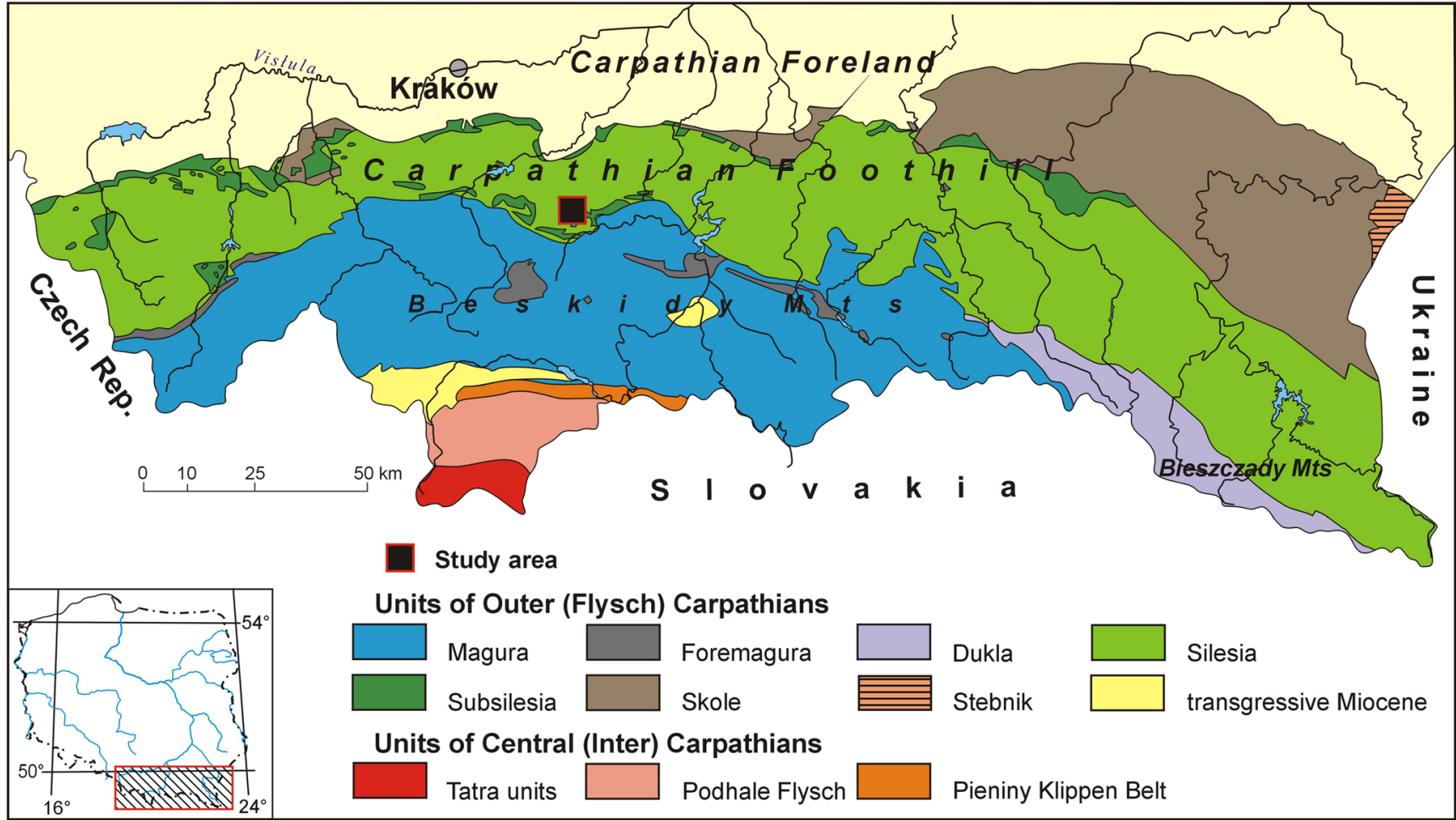

Fig. 2 The study area in relation to main structural units of the Polish Carpathians (geological map after Żytko et al. 1988-1989, simplified)

\section{Gorge of the Tarnawka River}

The approx. 3.5-km-long gorge of the Tarnawka River is one of the characteristic elements of the studied Natura 2000 area (Fig. 3). The beginning of the gorge in the Szyk Dolny locality is marked by a sharp bend of the river from the southeast to the north. Then, the river flows in a mild arc towards the east, and it loses its erosional nature in approx. $1.5 \mathrm{~km}$ before reaching the Tarnawa village. In the gorge, the river meanders between steep forested hills, elevated to 110-140 $\mathrm{m}$ above the rocky bottom of the valley. The width of the bottom of the meandering river valley is very variable; initially, it is approx. 10 to $20 \mathrm{~m}$, and then, it increases with the length of the course, usually to $50 \mathrm{~m}$, and even to $200 \mathrm{~m}$ at some places. In the cross section of the gorge valley, the asymmetry of slopes of the surrounding hills can be seen (Fig. 3). In its upper section, the inclination of slopes reaches $42^{\circ}$, particularly above the orographically left bank of the Tarnawka River (Fig. 3(A$\left.\mathrm{A}^{\prime}, \mathrm{B}-\mathrm{B}^{\prime}\right)$ ). In the middle fragment of the gorge, a similar high inclination of slopes occurs just above its right fringe, whereas the opposite slopes gradually reduce their heights (Fig. 3(C-C')). In the final stage of the gorge, the inclination of the left-bank slopes decreases and the cross section of the valley becomes increasingly asymmetrical (Fig. 3(D-D')). Just below the gorge, the valley of the meandering river markedly widens, and at the mouth to the Stradomka River, it is already $500 \mathrm{~m}$ wide.
The gorge of the Tarnawka River emerged in the zone of dislocations renewed by the movements of the Magura Nappe on the foreland. The decisive effect on its formation came from the lithological nature of the Istebna Formation of the Silesian Nappe, represented by thick-bedded sandstones of the Lower Istebna layers. They occur between the chaotic formations of the sub-Silesian and Silesian series, seen above the gorge, and the complex of sandstones and shales of the Upper Istebna layers, which are less resistant to erosion, is exposed below the gorge near Tarnawa.

\section{Rocky Landforms}

As in other areas of the Outer (Flysch) Carpathians, the natural outcrops of sandstones in the Tarnawka River are particularly valuable as interesting objects for scientific, educational, and geotourist studies (Alexandrowicz 2008). In this case, they represent the Istebna Sandstone Formation, which is an important lithological-sedimentation type, marked in the landscape of a given area by particularly interesting rocky landforms associated with the development of erosion and gravitational mass movements, as well as with the weathering processes. In various places in the gorge section of the Tarnawka River, there are the resistant beds of sandstones formed into a series of low thresholds, separated by thin layers of shales and marls (Fig. 4). On the steep slopes of hills, and especially along the Tarnawka River banks, the fissured outcrops of sandstones breaking up into blocks can be noted. At times, 


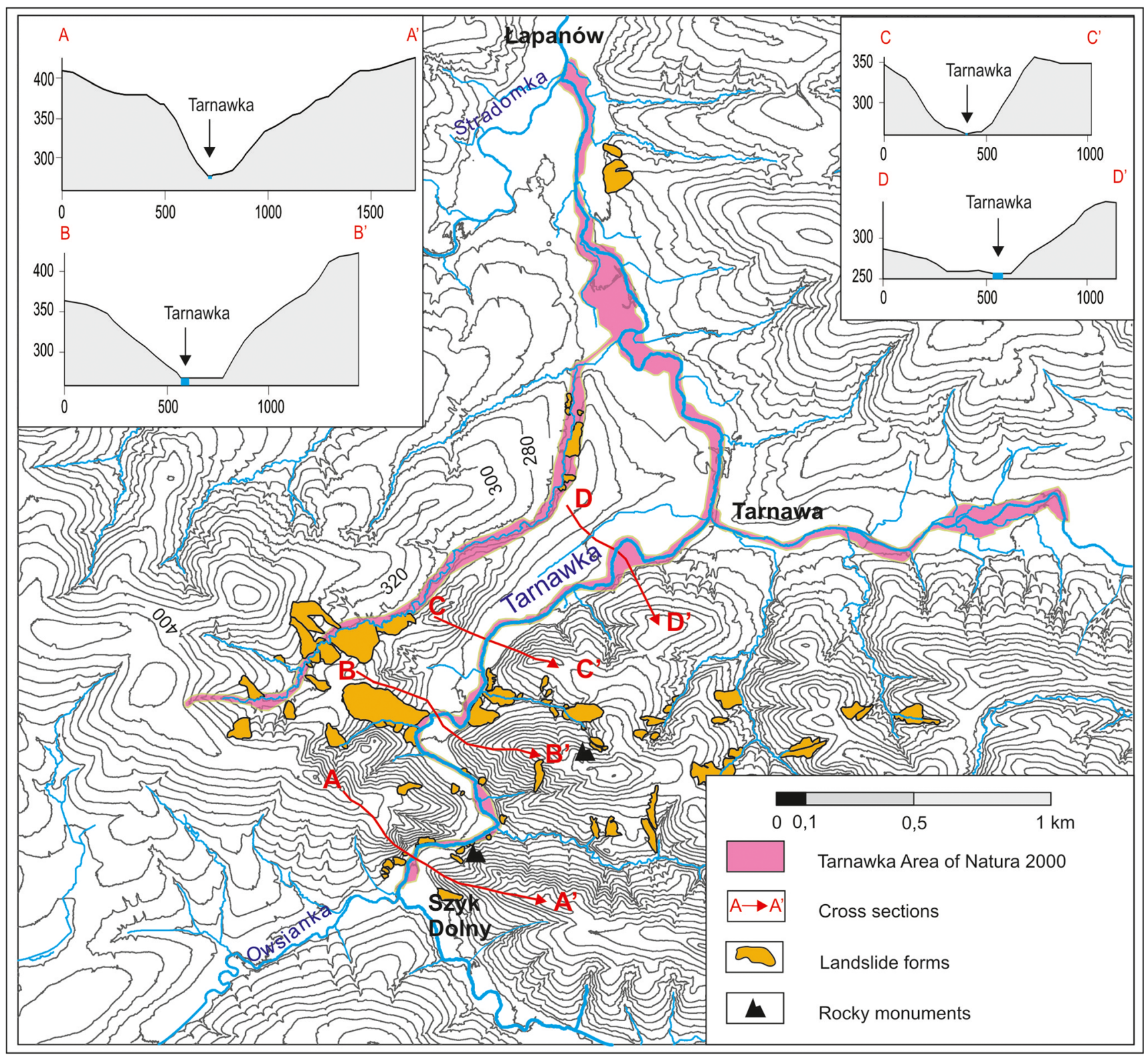

Fig. 3 The relief of Tarnawka gorge valley and its surrounding

Fig. 4 The fragment of the

Tarnawka River gorge valley

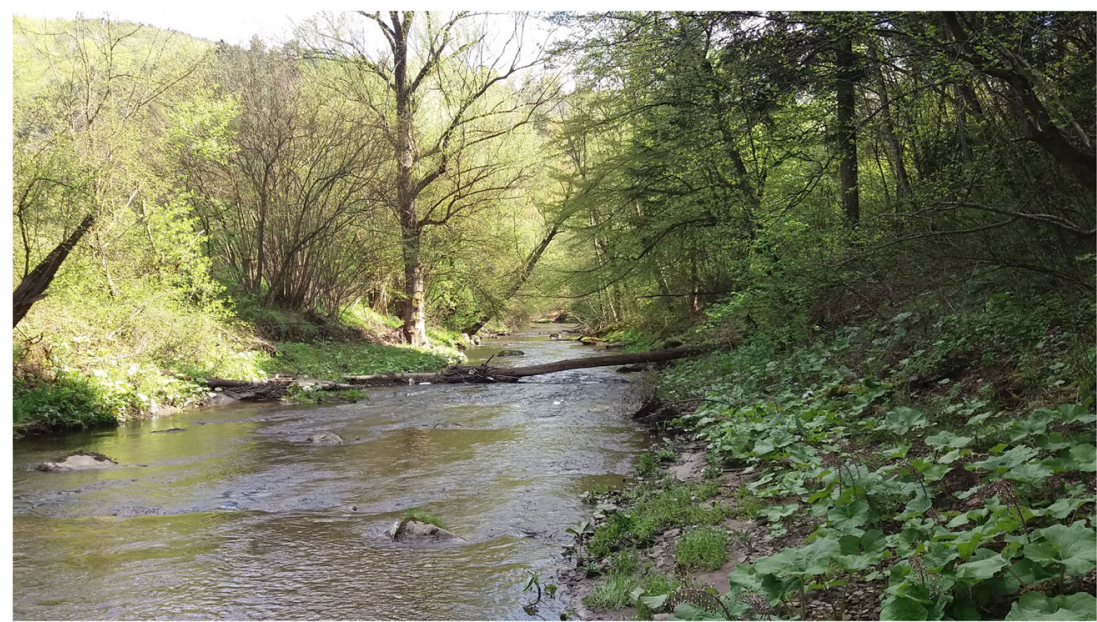


these lead to the damage and deformation of trees. The steep hill slopes are divided by a dense network of gorges that are mostly temporarily watered (Fig. 3). Within them, there are numerous forms produced by the slumped weathered debris covers, as well as various sizes of rock packets.

The selected, instructive example among landslide forms is usually called Wielki Kamień (Great Stone) occurring just above the Tarnawka River valley, at the end of the side ridge of Szykowska Góra (452 m a.s.l.) (Figs. 1 and 5). It was once the most exposed fragment of the rock ridge of the initial section of the gorge valley, but it now is completely hidden in woods. The rock outcrop spans $20 \mathrm{~m}$ long and $8-10 \mathrm{~m}$ wide along the ridge. It is inclined approx. $50^{\circ}$ towards the northeast. Its spur-like ending is composed of thick sandstone beds with conglomerates and is elevated up to $10 \mathrm{~m}$ above the slope (Fig. 5a). The stratification of sandstone beds is diverse, e.g. there are also the lens of conglomerates and clay balls (Fig. 5b). The rocky ridge is separated by open fissures along tectonic joints, testifying to the advanced progression of gravitational processes. They lead to the slow sliding and settling of rock fragments on steep slopes, the falling of its overhanging parts, the accumulations of loose blocks, as well as the formation of rock shelters and caves. The cave studied to date is $7 \mathrm{~m}$ long.

The process of the disintegration of rock masses and relocations of its packets is brought about by the following causes: the loss of stability resulting from erosional deepening and side erosion of the river bed, the geological situation of the area in the zone of complicated overthrust of nappes with different bed sequences and tectonic structures, and the occurrence of clay shales separating thick sandstone complexes facilitating their sliding.

Grodziec Hill (423 m a.s.1.) contains an original rocky form that has been known under various names, but is now normally referred to as Żótw (Turtle), and Grodziec Hill is situated in an exceptional place and is suggested for protection (Klimaszewski 1932, 1947; Rotter 1976/77; Alexandrowicz 1978) (Figs. 1 and 6). It towers from the rocky ridge, leading to the place over the gorge where once a fortified settlement existed, and the remained fragmentary traces of it allowed the reconstruction of its past appearance (Leńczyk 1983). The rock is $8 \mathrm{~m}$ high on the northern side, and $5 \mathrm{~m}$ high on the southern side (Fig. 6a). It is a diagenetic concretion, which is exposed on the top ridge due to the resistance of sandstones and conglomerates whose mineral components are strongly cemented with iron compounds. The rock is characterised by diverse lithological composition, very variable bedding, and the presence of traces of erosional washes (Fig. 6b). Sandstones are coarse grained and poorly sorted, and like conglomerates, contain numerous fragments of exotic rocks, such as quartzites, hornstones, and the various varieties of limestones. The wall surfaces are clearly modelled by the processes of selective weathering.
The diverse sequences of sediments in the two rocks described as examples of the protected monuments of nature, which are different in terms of the situation of occurrence, represent the same type of deposit sedimentation. Their accumulation occurred in a deep-sea basin as a result of the participation of high density turbidity currents or gravity flows, also called fluxoturbidites (Dżułyński et al. 1959; Unrug 1963; Lowe 1982; Leszczyński 1989; Shanmugam 1996).

The gravel-sand formations of the Carpathian Flysch are characterised by very thick beds with heterogeneous and poorly sorted coarse-grained components that are unequally cemented. These are the most suitable for the development of rocky forms especially within lithosomes represented by fluxoturbidites (Alexandrowicz 1977, 1978). Sandstone complexes have been exposed in the relief by the active processes of the erosion and weathering during the Late Pleistocene Glacial and Holocene periods. The lithological characteristics of sandstones producing rock forms and the sedimentation properties showing the variety of bedding and erosional washing out of debris flows are clearly patterned on the rock wall due to the processes of selective weathering. The effects of contemporary transformations of the rock surfaces in the form of weathering crusts securing them periodically and their various stages of exfoliation are also evident (Alexandrowicz et al. 2014a) (Fig. 5a).

\section{Malacofauna as Indicator of the Environmental Changes}

Malacological analysis is used as one of the methods to study the effect of human activities upon the changes in the natural environment (Alexandrowicz and Alexandrowicz 2011). Because of the possibility to conduct local-scale reconstructions, the method is particularly useful in finding the diversity in the nature of natural habitats. It also provides the opportunity to characterise the most recent geological history of the studied area, while simultaneously indicating the diversity and directions of environmental changes in its particular parts. It should be emphasised that the conclusions drawn from the studies of the changes in the characteristics of natural habitats employing the subfossil molluscan assemblages permit one to obtain data that is essential and difficult-to-get by other methods.

Malacological analysis been used to find the anthropogenic changes in the early period of written history recorded in sediments forming low terraces in one of the streams of the Tarnawka River drainage area. The material for studies included 19 samples of fluvial sediments representing four profiles. The profiles are situated in the Owsianka Stream valley in the section between the village of Jodłownik and the mouth of the stream into the Tarnawka River (Fig. 1). Thus, they represent the neighbourhood situated south of the Natura 2000 area. All 

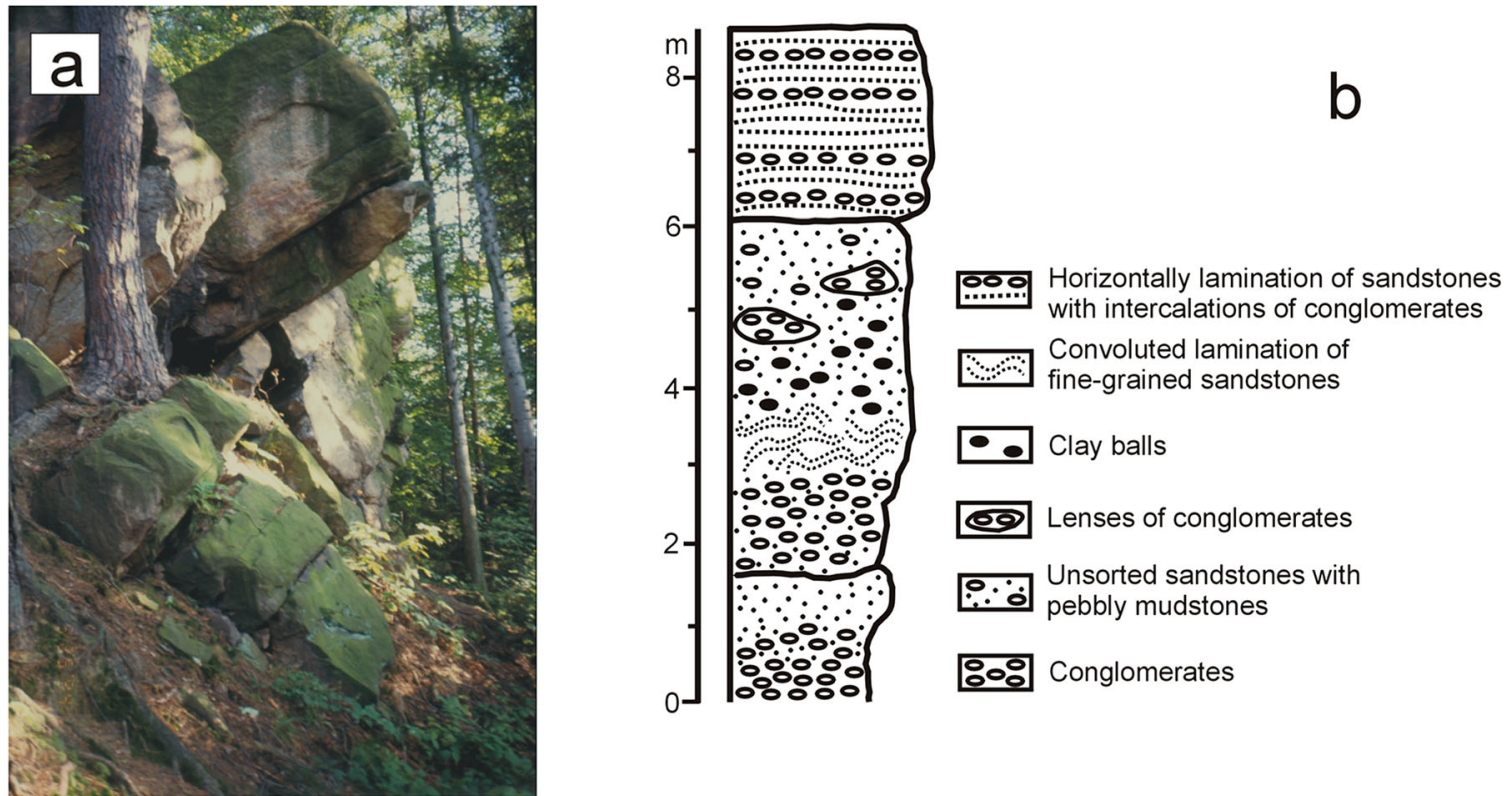

Fig. 5 Rocky forms gravitationally moving on the steep northern slope of the Szykowska Mont. a Fragment of the Big Stone scenery showing the disintegration of the thick-bedded Lower Istebna Sandstones and

the analysed profiles have similar forms of sediments. These are principally sandy or silty alluvial soils with the insertions of fine-grained gravels. In the floor part, coarse-grained gravels appear, and sometimes, the outcrops of flysch formations forming rock blocks appear. The thickness of sediments containing molluscan shells does not exceed $1 \mathrm{~m}$. The analysis of malacofauna was aimed at characterising the changes of exfoliation the weathering crusts. b Lithological and sedimentary sequences of beds exposed on the walls of Big Stone

natural environment in the Owsianka Stream valley, and particularly those associated with human activities. These activities undoubtedly had a profound effect on the processes occurring in the Tarnawka River drainage basin as well as in its part included in the Natura 2000 area.

The malacological studies included the description of outcrops, the collection of samples, and laboratory processing

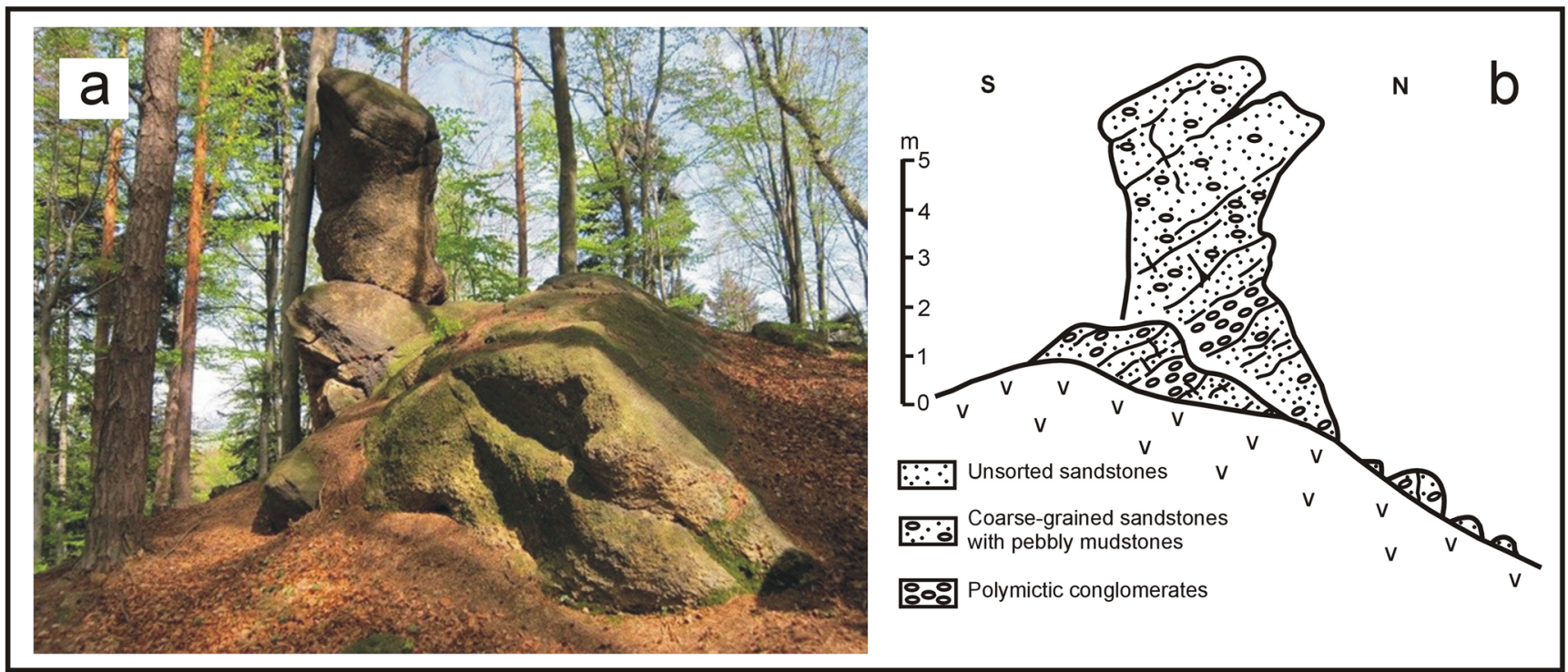

Fig. 6 Sandstone tor called Turtle on the Grodziec Hill. a The view from east (photo by W. Głowacki). b Tor view from west showing sedimentary sequences and its resistance to weathering processes of the Lower Istebna Sandstones 
Table 1 Malacofauna of the deposits of the Owsianka stream valley between Jodłownik and Szyk Dolny. E ecological groups of molluscs (based on Ložek 1964; Alexandrowicz and Alexandrowicz 2011),
F shade-loving species, O open-country species, M mesophilous species, W water species, SB symbol of species, Jd-I-Jd-IV profiles, 119 samples

\begin{tabular}{|c|c|c|c|c|c|c|}
\hline \multirow[t]{2}{*}{$\mathrm{E}$} & \multirow[t]{2}{*}{ Taxon } & \multirow[t]{2}{*}{ SB } & \multicolumn{4}{|c|}{ Profiles } \\
\hline & & & Jd-I & Jd-II & Jd-III & Jd-IV \\
\hline $\mathrm{F}$ & Platyla polita (Hartm.) & $\mathrm{Pp}$ & 1 & 28 & & \\
\hline $\mathrm{F}$ & Ena montana (Drap.) & Em & 1 & 3 & 4 & \\
\hline $\mathrm{F}$ & Acanthinula aculeata (Müll.) & $\mathrm{Aa}$ & & 4 & & \\
\hline $\mathrm{F}$ & Daudebardia rufa (Drap.) & Df & & 12 & & \\
\hline $\mathrm{F}$ & Eucobresia nivalis (Dum. et Mort.) & En & & 2 & & \\
\hline $\mathrm{F}$ & Discus perspectives (Mühlf) & $\mathrm{Dp}$ & & 40 & & \\
\hline $\mathrm{F}$ & Discus rotundatus (Müll.) & $\mathrm{Dr}$ & & 10 & & \\
\hline $\mathrm{F}$ & Vitrea diaphana (Stud.) & $\mathrm{Vd}$ & & 39 & & \\
\hline $\mathrm{F}$ & Vitrea transsylvanica (Cless.) & $\mathrm{Vt}$ & & 7 & & \\
\hline $\mathrm{F}$ & Vitrea crystallina (Müll.) & $\mathrm{Vc}$ & & 63 & 8 & 18 \\
\hline $\mathrm{F}$ & Aegopinella minor (Stabile) & $\mathrm{Am}$ & & 21 & & \\
\hline $\mathrm{F}$ & Aegopinella pura (Ald.) & Ap & & 49 & & \\
\hline $\mathrm{F}$ & Ruthenica filograna (Rossm.) & $\mathrm{Rf}$ & & 6 & & \\
\hline $\mathrm{F}$ & Cochlodina laminata (Mont.) & $\mathrm{Cl}$ & & 2 & & \\
\hline $\mathrm{F}$ & Alinda biplicata (Mont.) & $\mathrm{Ab}$ & 7 & 8 & & \\
\hline $\mathrm{F}$ & Vestia gulo (Bielz) & $\mathrm{Vg}$ & & 45 & & \\
\hline $\mathrm{F}$ & Vestia turgida (Rossm.) & $\mathrm{Vt}$ & 1 & 25 & & \\
\hline $\mathrm{F}$ & Fruticicola fruticum (Müll.) & $\mathrm{Ff}$ & & 41 & 3 & \\
\hline $\mathrm{F}$ & Perforatella bidentata (Gmel.) & $\mathrm{Pb}$ & 11 & 72 & 1 & \\
\hline $\mathrm{F}$ & Monachoides incarnatus (Müll.) & $\mathrm{Mi}$ & 2 & 55 & 2 & 2 \\
\hline $\mathrm{F}$ & Monachoides vicinus (Rossm.) & $\mathrm{Mv}$ & & 63 & 3 & \\
\hline $\mathrm{F}$ & Isognomostoma isognomostomos (Schröt.) & Ii & & 13 & 7 & \\
\hline $\mathrm{F}$ & Chilostoma faustinum (Rossm) & $\mathrm{Cf}$ & & 11 & & \\
\hline $\mathrm{F}$ & Helix pomatia $(\mathrm{L})$. & Hp & & 3 & & \\
\hline $\mathrm{O}$ & Vertigo pygmaea (Drap.) & $\mathrm{Vp}$ & 2 & & & \\
\hline $\mathrm{O}$ & Pupilla muscorum (L.) & $\mathrm{Pm}$ & 12 & 7 & 3 & 4 \\
\hline $\mathrm{O}$ & Vallonia costata (Müll.) & Vs & 9 & & & 54 \\
\hline $\mathrm{O}$ & Vallonia pulchella (Müll.) & $\mathrm{Vl}$ & 59 & 8 & 41 & 217 \\
\hline $\mathrm{O}$ & Cecilioides acicula (Müll.) & $\mathrm{Ca}$ & & & & 39 \\
\hline M & Carychium tridentatum (Risso) & $\mathrm{Ct}$ & 1 & 108 & & \\
\hline M & Cochlicopa lubrica (Müll.) & $\mathrm{Cb}$ & 29 & 19 & 11 & 30 \\
\hline M & Succinella oblonga Drap. & So & 19 & 41 & 10 & 27 \\
\hline M & Columella edentula (Drap.) & $\mathrm{Ce}$ & & 4 & & \\
\hline M & Punctum pygmaeum (Drap.) & $\mathrm{Pg}$ & & 1 & & \\
\hline M & Vitrea contracta (West.) & $\mathrm{Vn}$ & & 56 & & \\
\hline M & Perpolita hammonis (Ström) & $\mathrm{Ph}$ & & 2 & & 17 \\
\hline M & Limacidae & $\mathrm{Li}$ & 6 & 7 & 20 & 7 \\
\hline M & Clausilia dubia Drap. & $\mathrm{Cd}$ & 1 & 2 & 1 & \\
\hline M & Laciniaria plicata (Drap.) & $\mathrm{Lp}$ & & 1 & 4 & \\
\hline W & Bythinella austriaca (Fér) & $\mathrm{Ba}$ & & 211 & 15 & \\
\hline W & Galba truncatula (Müll.) & Gt & 4 & & & \\
\hline W & Pisidium casertanum (Poli) & $\mathrm{Pc}$ & & 19 & & \\
\hline W & Pisidium personatum Malm & $\operatorname{Pr}$ & & 62 & & \\
\hline \multicolumn{2}{|c|}{ Total species } & & 23 & 39 & 15 & 10 \\
\hline \multicolumn{2}{|c|}{ Total specimens } & & 100 & 1170 & 133 & 415 \\
\hline \multicolumn{3}{|c|}{ Indeterminate shell fragments } & 33 & 217 & 71 & 92 \\
\hline
\end{tabular}

(flushing, drying, the removal of molluscan shells, and identifying the fauna as well as finding the numbers of particular taxa). This material provided the basis of the reconstruction of environmental changes carried out in accordance with the standard methods of malacological analysis described by Ložek (1964) and Alexandrowicz and Alexandrowicz
(2011). The malacological profiles are characterised by small thicknesses and little diversification of fauna. Its composition and structure was presented in combined malacological spectra. The basis for separating fauna assemblages was the analysis of the dendrogram prepared applying the formula defined by Morisita (1959), which was performed with the use of the 
Fig. 7 Ecological and taxonomical composition of malacofauna from deposits of the Owsianka stream valley between Jodłownik and Szyk Dolny

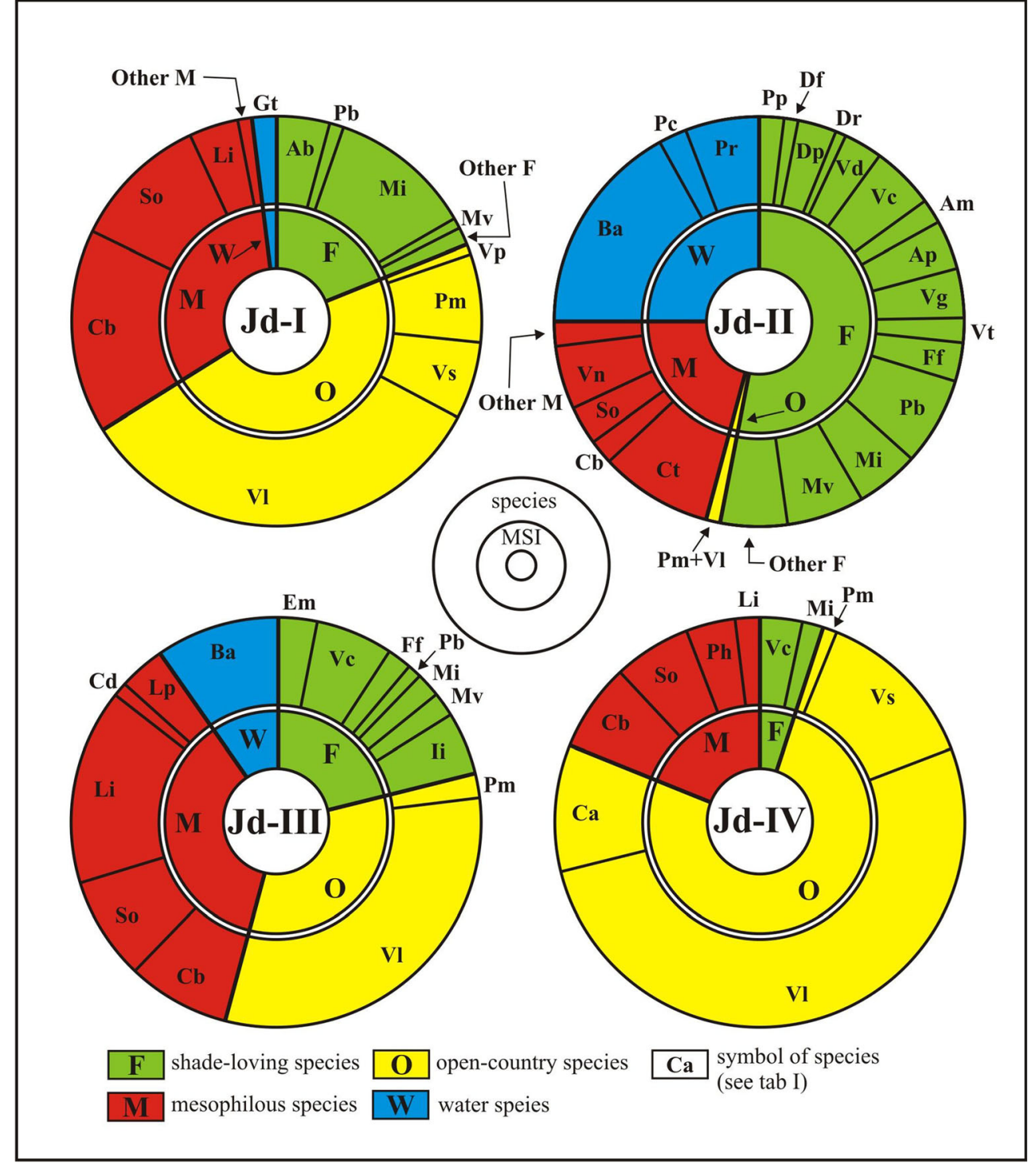

PAST software package (Hammer et al. 2001). The dendrogram enables grouping of samples which are characterised by similar species composition and the structure of assemblage. Owing to these, it allows pooling the samples and the malacofauna occurring in them with a specific type of habitat and - as a consequence - the palaeographic reconstructions pertaining to the principal phases of the environmental changes in the described area. The stratigraphic position of sediments was found indirectly, based on comparisons with other similar profiles described in the neighbouring areas as well as directly through radiocarbon dating. The result of dating was calibrated by the use of the OxCal 4.2 software package (Bronk Ramsey 2009).

The shell material included 43 taxa of molluscs ( 39 species of terrestrial snails, 2 species of water snails, and 2 species of mussels), representing a combined number of nearly 1900 specimens. The numbers of taxa occurring in particular samples varied from 6 to 34, and the number of specimens varied from 14 to 322 (Table 1).

The ecological structure and species composition of the malacofauna identified in particular profiles are presented in Table 1 and Fig. 7. The shadow-loving species are the characteristic and predominant component in profiles Jd-I and JdII (Fig. 7, Table 1). Both snails inhabiting dense forests (Aegopinella pura, Ruthenica filigrana, Discus perspectivus), the forms typical of translucent forests and shrubby zones (Fruticicola fruticum, Discus rotundatus), and shadowloving species typical of moist habitats (Perforatella bidentata, Monachoides vicinus) are present, and their combined share exceeds 50\%. In profiles Jd-III and Jd-IV (Fig. 1), the shadow-loving molluscs are practically absent. Their place is occupied by the snails of open grassy habitats (Vallonia pulchella and Vallonia costata). Worth mentioning is the presence of Cecilioides acicula, which is an index taxon for 


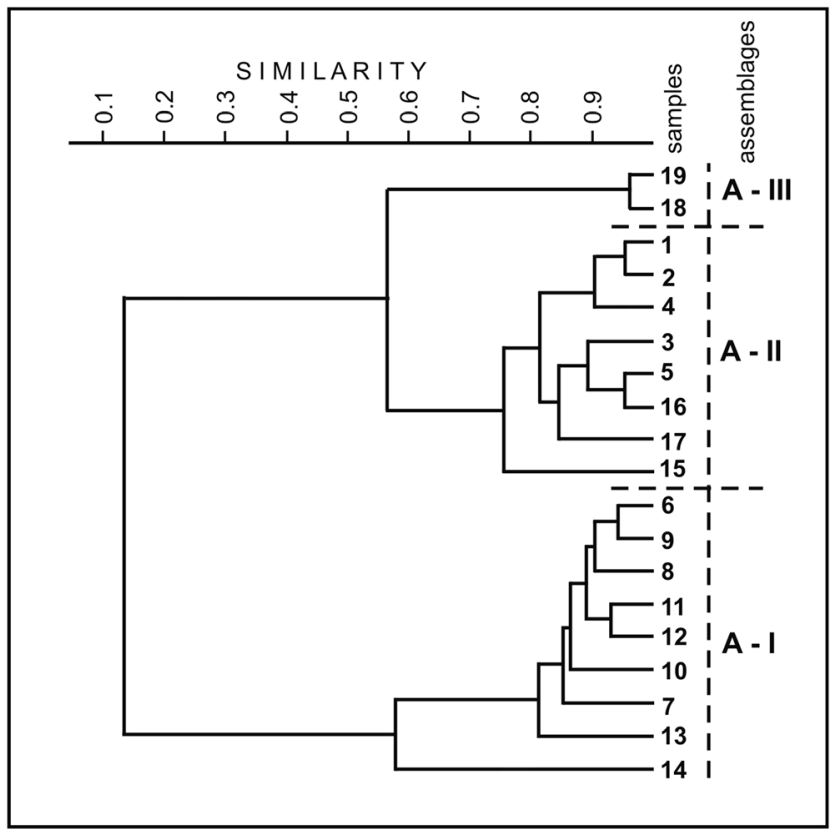

Fig. 8 Cluster analysis of the malacofauna from deposits of the Owsianka stream valley between Jodłownik and Szyk Dolny

agricultural areas. Water molluscs are represented by the taxa typical for spring zones and running waters (Bythinella austriaca, Pisidium personatum). Relatively numerous mesophilous species and evidently rarer hygrophiles are complementary components (Fig. 7, Table 1).

The analysis of the dendrogram (Fig. 8) indicates the presence of three different fauna assemblages. The first fauna (AI) occurs in the profile Jd-II and is characterised by the predomination of shade-loving species and abundant occurrence of Bythinella austriaca and Pisidium personatum. This fauna is typical of shaded habitats of variable moisture levels and the presence of fast-moving mountain streams. The second type of fauna (A-II) appears in the profiles Jd-I and Jd-III. It is characterised by a poor species composition, and the predomination of snails is typical of open grassy biotopes (Vallonia pulchella and Vallonia costata). The third type (A-III) is similar to the type represented by A-II, but it contains numerous shells of Cecilioides acicula.

The knowledge of the history of human settlements in the Owsianka Stream valley is essential to the characterising of the diversification of the molluscan assemblages identified there. The oldest records of the village of Jodłownik date back to the fourteenth century. This period can be linked with the influx of human groups into the area and with the onset of anthropogenic pressure manifested primarily by disappearance of forests, and replacing them by open grassland habitats, and later, by arable fields. Viewed from this perspective, the assemblage identified in the Jd-II profile (fauna of A-I type) with a considerable proportion of forest species should be considered the oldest. Its stratigraphic position can be indirectly ascertained based on the presence of Bythinella austriaca.
This species is the common component of malacoenoses representing the period of written history. It was noted in very numerous sites of sediments dated as not older than 1000 years in the Podhale Basin, (Alexandrowicz 2010, Alexandrowicz 2013; Alexandrowicz and Rybska 2013; Alexandrowicz et al. 2014a, b), the Pieniny Mts (Alexandrowicz 2004a, b, 2010; Alexandrowicz et al. 2016), and in the Flysch Carpathians (Alexandrowicz 2004a, b, 2009). The significant proportion of shade-loving species indicated that the malacoenosis in question corresponds to the phase preceding intensive settlement activities. It is likely that the age of the floor part of the alluvial soil series in the profile represented by Jd-I (1380 \pm 70 years BP (581-694 and 747763 cal AD)) corresponds to just this period (Fig. 9). The intensified settlement activities falling on the period of the fourteenth century is a phenomenon commonly observed in the Carpathian Foothills, and within intermontane basins (Alexandrowicz and Alexandrowicz 1995; Alexandrowicz 2004a, b, 2013). It can be associated with the phase of warm climate, which is called the "Medieval Climatic Optimum" (Grove and Swistur 1994; Hughes and Diaz 1995; Bradley 2000; Briffa 2000). The increase in human population numbers had a significant effect on the environment, with deforestation as its main symptom. The replacement of forests by open grassland habitats led to the impoverishment of malacoenoses as well as to significant reconstruction of their species compositions and structures. The accumulations of sandy alluvial soils identified in Jd-I and Jd-III profiles containing poor fauna assemblage where the main components are snails typical of open environments, and mesophilous forms (fauna of A-II type), can be associated with this period. The intensification of erosion, which led to the formation of an approx. 4-m-high terrace along the Owsianka Stream valley, can be linked with increasingly cool and moist climate prevailing during the sixteenth and seventeenth centuries (Fig. 9). This phase corresponds to the older part of the Little Ice Age (Bradley and Jones 1993; Bradley 2000; Briffa 2000; Jones and Mann 2004). Similar phenomena are observed in valleys of a number of Carpathian rivers (Starkel 1960, 1985, 1996, 2005; Starkel et al. 2006; Alexandrowicz 2013). The youngest malacoenosis identified with the low terrace is characterised by the occurrence of many Cecilioides acicula shells, indicating the presence of arable lands in close vicinity. The abovedescribed terrace is inserted into an older system, approx. $4 \mathrm{~m}$ high, which was formed during the older part of the Little Ice Age. In accordance with the data on the development of the river network and the intensity of fluvial processes in the Carpathians, the accumulation of the lowest system of terraces occurred at the break of the eighteenth and nineteenth centuries, whereas the cutting of sediments can be correlated with the increase in flood intensities falling on the second part of the nineteenth century (Starkel 2005; Gebica 2013; Gebica et al. 2016) (Fig. 9). 
Fig. 9 Environmental changes of Owsianka stream valley between Jodłownik and Szyk Dolny during historical times

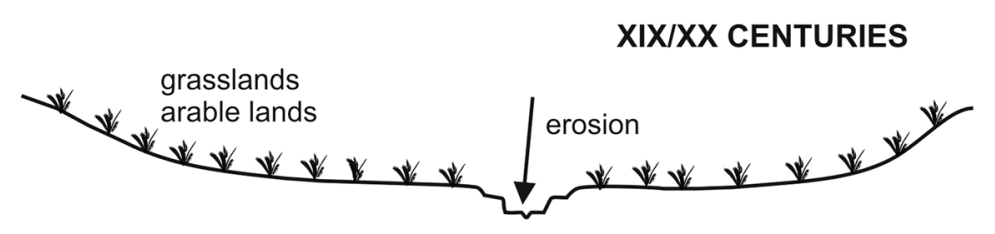

XVIII/XIX CENTURIES
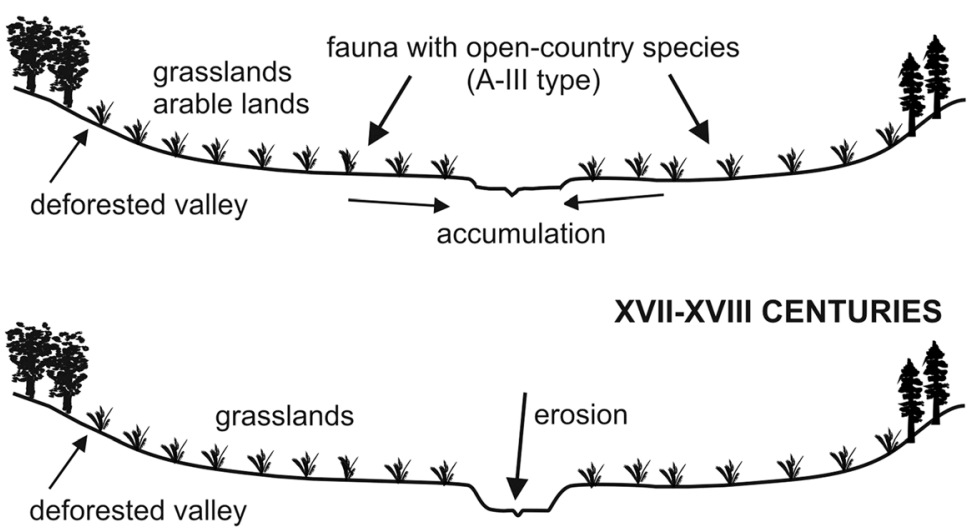

XIV-XVI CENTURIES

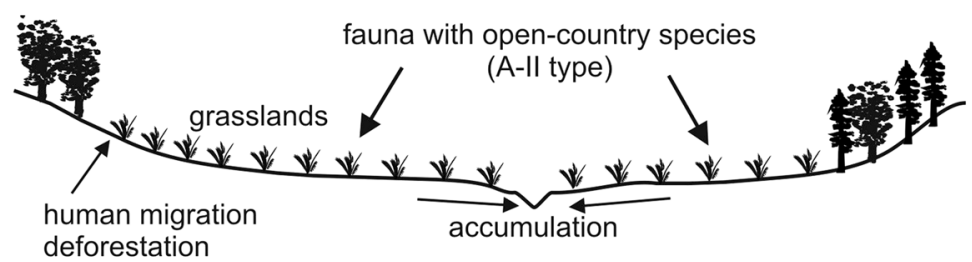

BEFORE XIV CENTURY

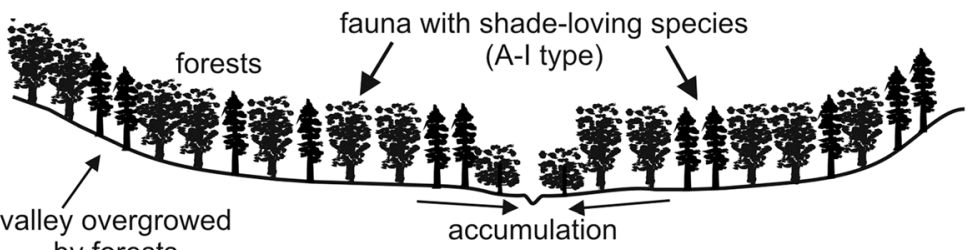

by forests

\section{Concluding Remarks}

The studies in the Natura 2000 site that encompasses the Tarnawka River valley, reaching into its geological and historical past, enriched the motives of its previous valuation. At the same time, the results obtained point to the need to extend the area in view of the good opportunity to present the diversity in the broader context of the natural habitats, typical of the valley and its surroundings in the Carpathian Foothills. Maintaining the conditions for the natural development of the whole drainage basin of the Tarnawka River will primarily require the introduction of a ban involving technical regulation of its course and its tributaries, a ban on building developments in the valleys, and a ban on the deforestation of hill slopes.

One of the most important elements which determines the natural values of protected areas is their unique and separate nature, particularly with respect to the features of the environment prevailing in their surroundings. Such diversity stems from a number of factors, natural components (geological structure, land relief, fauna and flora), and from the changes in the environment over time. In this second aspect, human activities are of particular significance. The possibility to reconstruct the phases, nature, and intensity of anthropogenic pressure is of fundamental significance to the functioning of 
protected areas and to the undertaking of adequate protective measures. On the one hand, the malacological analysis applied in the presented study indicated the presence of a phase of particularly intensive human activity and the dramatic change of environmental conditions in the immediate vicinity of the protected area. On the other hand, the narrow gorge section of the Tarnawka River valley, having a surface relief that is disadvantageous from the viewpoint of agricultural management (steep, partly rocky slopes), has principally retained its natural character, representing the features of habitats from before the phase of intensive settlement activities. The malacological studies indicated that the protected section of the Tarnawka River valley retained its distinction throughout several of the most recent centuries. This fact underscores its major natural values and the necessity for protecting it. It also indicates the purposefulness of undertaking malacological analyses when developing the characteristics of protected areas.

The current data on the abiotic elements of natural habitats in the national Natura 2000 areas are generally not sufficient for forecasting their natural and/or anthropogenic changes and threats. As a consequence, keeping the relatively permanent state of affairs for retaining the required habitat conditions is problematic unless the countermeasures against threats via other protective measures or economic use of the area are not attempted in a sufficient time. After the 25 -year long process of creating the Natura 2000 network, its functioning can provide a convincing argument that (not only in the areas covered by monitoring schemes) there is an interdependence between the occurrence of abiotic and biotic elements in various types of natural habitats. The current challenge is a formal recognition of this integrity in the implementation of the plans of Natura 2000.

The integration of geodiversity and biodiversity is interdependent and cohesive parts of nature in all protected areas, and this was one of the main messages recommended in the Declaration of the VIII International ProGEO Symposium held in Reykjavik in 2015 (Declaration of Reykjavik 2015). The strategy of this message pertaining to the Ecological Network Natura 2000 requires the application of a relevant EU directive that would demand recording and checking the status as well as protecting of abiotic elements of natural habitats.

Acknowledgments Special thanks for Professor dr hab Stefan Witold Alexandrowicz for malacological materials.

Funding information Molluscan analysis has been sponsored by the AGH University of Science and Technology through the University grant no 11.11.140.005.

Open Access This article is distributed under the terms of the Creative Commons Attribution 4.0 International License (http:// creativecommons.org/licenses/by/4.0/), which permits unrestricted use, distribution, and reproduction in any medium, provided you give appropriate credit to the original author(s) and the source, provide a link to the Creative Commons license, and indicate if changes were made.

\section{References}

Alexandrowicz Z (1977) The origin of sandstone tors in the Polish Western Carpathians. Bull Acad Pol Sci Sci Terre 25(2):83-90

Alexandrowicz Z (1978) Skałki piaskowcowe zachodnich Karpat fliszowych (Engl. summ. Sandstone tors of the Western Flysch Carpathians). Prace Geologiczne Komisji Nauk Geol PAN Oddz w Krakowie 113:1-87

Alexandrowicz WP (2004a) Molluscan assemblages of Late Glacial and Holocene calcareous tufas in Southern Poland. Folia Ouaternaria 75: $1-309$

Alexandrowicz Z (2004b) Important geosites of Poland in relation to the Ecological Network Natura 2000. In: Ber A, Alexandrowicz Z, Balabanis P (eds) Geological heritage concept, conservation and protection policy in Central Europe. Polish Geological Institute, Special Papers 13, pp 41-48

Alexandrowicz Z (2008) Sandstone rocky forms in the Polish Carpathians attractive for education and tourism. Prz Geol 56(8/1): 680-687

Alexandrowicz WP (2009) Malakofauna górnoholoceńskich martwic wapiennych w Beskidach Zachodnich (południowa Polska) (Engl. summ. Malacofauna of Upper Holocene calcareous tufa in the Western Beskidy Mts (Southern Poland)). Geologia Kwartalnik AGH 35:175-200

Alexandrowicz WP (2010) Molluscan assemblages of recent calcareous tufa in Podhale Basin and Pieniny Mts (Southern Poland). Folia Malacol 18(3):99-112

Alexandrowicz WP (2013) Molluscan communities in Late Holocene fluvial deposits as an indicator of human activity: a study in Podhale Basin in South Poland. Ekologia Bratislava 32:111-125

Alexandrowicz SW, Alexandrowicz WP (1995) Quaternary molluscan assemblages of the Polish Carpathians. Studia Geomorphologica Carpatho-Balcanica 29:41-54

Alexandrowicz SW, Alexandrowicz Z (2006) Rocky edge and malacocenoses of the Żurawnica Ridge (Polish Western Carpathians). Ekológia (Bratislava) 25(2):151-165

Alexandrowicz SW, Alexandrowicz WP (2011) Analiza malakologiczna metody badań i interpretacji (Engl. summ. Malacological analyses methods of investigation and interpretation). Rozpr Wydz Przyrodniczego PAU 3:5-302

Alexandrowicz Z, Margielewski W (2010) Impact of mass movements on geo- and biodiversity in the Polish Outer (Flysch) Carpathians. Geomorphology 123:290-304

Alexandrowicz WP, Rybska E (2013) Environmental changes of intramontane basins derived from malacological analysis of profile of calcareous tufa in Niedzica (Podhale Basin, Southern Poland). Carpathian J Earth Environ Sci 8(4):13-26

Alexandrowicz Z, Dyduch-Falniowska A, Mróz W (2004a) The Pattern of geo- and biodiversity conservation in Poland, In: Parkes MA (ed.) Natural and cultural landscapes - the geological foundation. Proceedings of a Conference, Royal Irish Academy, Dublin 2002, pp 53-56

Alexandrowicz Z, Margielewski W, Perzanowska J (2004b) European Ecological Network NATURA 2000 in relation to landslide areas diversity: a case study in the Polish Carpathians. Ekológia (Bratislava) 22(4):404-422

Alexandrowicz WP, Szymanek M, Rybska E (2014a) Changes to the environment of intramontane basins in the light of malacological research of calcareous tufa: Podhale Basin (Carpathians, Southern Poland). Quat Int 353:250-265

Alexandrowicz Z, Marszałek M, Rzepa G (2014b) Distribution of secondary minerals in crusts developed on sandstone exposures. Earth Surf Process Landf 39:320-335

Alexandrowicz WP, Szymanek M, Rybska E (2016) Molluscan assemblages from Holocene calcareous tufa and their significance for 
palaeoenvironmental reconstructions. A study in the Pieniny Mountains (Carpathians, southern Poland). Carpathian J Earth Environ Sci 11:37-54

Bradley RS (2000) Past global changes and their significance for the future. Quat Sci Rev 19:391-402

Bradley RS, Jones PD (1993) 'Little Ice Age' summer temperature variations: their nature and relevance to recent global warming trends. The Holocene 3:367-376

Brancucci G, Burlando M, Marin V, Paliaga G (2004) The role of geological heritage in the Natura 2000 network (Habitats Directive, 92/ 43/EEC): a local study in northern Italy (Liguria Region). In: Parkes MA (ed.) Natural and cultural landscapes - the geological foundation. Proceedings of a Conference, Royal Irish Academy, Dublin 2002, pp 57-60

Briffa KR (2000) Annual climate variability in the Holocene: interpreting the message of ancient trees. Quat Sci Rev 19:87-105

Bronk Ramsey C (2009) Bayesian analysis of radiocarbon dates. Radiocarbon 51:331-306

Burtan J, Skoczylas-Ciszewska K (1964) Szczegółowa Mapa Geologiczna Polski (bez utworów czwartorzędowych) 1: 50 000, arkusz Limanowa, wydanie tymczasowe, Wydawnictwo Geologiczne, Warszawa

Declaration of Reykjavik (2015) News ProGeo 3:8

Dżułyński S, Książkiewicz M, Kuenen PH (1959) Turbidites in flysch of the Polish Carpathian Mountains. Geol Soc Am Bull 70:1089-1118

Gębica P (2013) Geomorphological records of human activity reflected in fluvial sediments in the Carpathians and their foreland. Landform Anal 22:21-31

Gębica P, Jacyszyn A, Krapiec M, Budek A, Czumak N, Starkel L, Andrejczuk W, Ridush B (2016) Stratigraphy of alluvia and phases of the Holocene floods in the valleys of the Eastern Carpathians foreland. Quat Int 415:55-66

Gill JL, Blois JL, Benito B, Dobrowski S, Hunter ML Jr, McGuire JL (2015) A 2.5-million-year perspective on coarse-filter strategies for conserving nature's stage. Conserv Biol 29(3):640-648

Gray M (2013) Geodiversity valuing and conserving abiotic nature, 2nd edn. Wiley Blackwell, London

Grove JM, Swistur R (1994) Glacial geological evidence for the Medieval Warm Period. Clim Chang 26:143-169

Hammer Ø, Harper DAT, Ryan PD (2001) Past: paleontological statistics software package for education and data analysis. Palaeontol Electron 4:1-9

Hjort J, Gordon JE, Grey M, Hunter ML Jr (2015) Why geodiversity matters in valuing nature's stage. Conserv Biol 29(3):630-639

Hughes MK, Diaz HF (1995) Was there a 'Medieval Warm Period' and if so, when and where? Clim Chang 26:109-142

Iojă JC, Hossu CA, Niță MR, Onose DA, Badiu DL, Manolache S (2016) Indicators for environment conflict monitoring in Natura 2000 sites. International Conference - Environment conflict monitoring in Natura 2000 sites. Procedia Environ Sci 32:4-11

Jankowski L, Margielewski W (2014) Strukturalne uwarunkowania rozwoju rzeźby Karpat zewnętrznych - nowe spojrzenie (Abstract. Structural control of the Outer Carpathians relief - a now approach.). Prz Geol 62(1):29-35

Jones PD, Mann ME (2004) Climate over past millennia. Rev Geophys 42:1-42

Klimaszewski M (1932) "Grzyby skalne” na pogórzu karpackiem między Rabą a Dunajcem. Ochrona Przyrody, Rocznik 12:64-70

Klimaszewski M (1947) Osobliwości skalne w Beskidach Zachodnich. Wierchy 17:57-71
Lawler JJ, Ackerly DD, Albano CM, Anderson MG, Dobrowski SZ, Gill JJ, Heller NE, Pressey RL, Sanderson EW, Weiss SB (2015) The theory behind, and challenges of, conserving nature's stage in a time of rapid change. Conserv Biol 29(3):618-629

Leńczyk G (1983) Katalog grodzisk i zamczysk z terenu Małopolski. Muzeum Archeologiczne, Kraków

Leszczyński S (1989) Characteristics and origin of fluxoturbidites from the Carpathian flysch (Cretaceous - Palaeogene), South Poland. Ann Soc Geol Pol 59:351-390

Lowe DR (1982) Sediment gravity flows: II. Depositional models with special reference to the deposits of high-density turbidity currents. J Sediment Petrol 52:279-297

Ložek V (1964) Quartärmollusken der Tschechoslowakei. Rozpravy Ustredniho Ustavu Geologického 31:1-374

Marszałek J (1993) Katalog grodzisk i zamczysk w Karpatach. Wydawnictwo Stanisław Kryciński, Warszawa

Matthews TJ (2014) Integrating geoconservation and biodiversity conservation: theoretical foundations and conservation recommendations in a European Union context. Geoheritage 6(1):57-70

Morisita M (1959) Measuring of interspecific association and similarity between communities. Memoirs of the Faculty of Sciences, Kyushu University E, 3:65-80

Mróz W, Perzanowska J (2001) Dyrektywa Siedliskowa: siedliska przyrodnicze o znaczeniu europejskim w Polsce. Chrońmy Przyrodę Ojczystą 57(5):55-73

Naylor LA, Viles HA, Carter NEA (2002) Biogeomorphology revisited: looking towards the future. Geomorphology 47(1):3-14

Perzanowska J, Grzegorczyk M (eds) (2009) Obszary Natura 2000 w Małopolsce. Instytut Ochrony Przyrody PAN, Kraków

Radwanek-Bąk B (ed), Bąk B, Kopciowski R, Laskowicz I, Szelag A, Wójcik A (2009) Georóżnorodność i atrakcje geoturystyczne województwa małopolskiego. Przewodnik. Mapy Geoturystyczne. Państwowy Instytut Geologiczny - Państwowy Instytut Badawczy. Wydawnictwo Kartograficzne Compass, Kraków

Rotter A (1976/77) Przyczynek do poznania form skalnych Pogórza Wielickiego. Karpaty 1(2):7-9

Shanmugam G (1996) High-density turbidity currents: are they sandy debris flow? J Sediment Res 66:2-10

Starkel L (1960) Rozwój rzeźby Karpat fliszowych w holocenie. Prace Geograficzne IGPAN 22:5-281

Starkel L (1985) The reflection of the Holocene climatic variations in the slope and fluvial deposits and forms in the European mountains. Ecología Mediterránea 11:91-97

Starkel L (1996) Geomorphic role of extreme rainfalls in the Polish Carpathians. Studia Geomorphologica Carpatho-Balcanica 30:2138

Starkel L (2005) Role of climatic and anthropogenic factors accelerating soil erosion and fluvial activity in Central Europe. Studia Quaternaria 22:27-33

Starkel L, Soja R, Michczyńska DJ (2006) Past hydrological events reflected in Holocene history of Polish rivers. Catena 66:24-33

Unrug R (1963) Istebna beds - a fluxoturbidity formation in the Carpathian Flysch. Rocz Pol Towarz Geol 33(1):51-92

Wacławik W, Bajer A (eds) (2014) Beskid Wyspowy. Mapa turystyczna 1:65, vol 000. Wyd. ExpressMap, Warszawa

Żytko K, Zając R, Gucik S, Ryłko W, Oszczypko N, Garlicka I (19881989) Map of the tectonic elements of the western outer Carpathians and their foreland, In: Poprawa D and Nemčok J (eds) Geological atlas of the western outer Carpathians and their foreland. PIG Warszawa, GUDS - Bratislava, UUG - Praha 